\title{
A new phenylethanoid triglycoside in Veronica beccabunga $L$
}

\author{
Jensen, Søren Rosendal; Opitz, Sebastian Ed. Wieland; Gotfredsen, Charlotte Held
}

\section{Published in:}

Biochemical Systematics and Ecology

Link to article, DOI:

10.1016/j.bse.2011.02.008

Publication date:

2011

Document Version

Early version, also known as pre-print

Link back to DTU Orbit

Citation (APA):

Jensen, S. R., Opitz, S. E. W., \& Gotfredsen, C. H. (2011). A new phenylethanoid triglycoside in Veronica beccabunga L. Biochemical Systematics and Ecology, 39(3), 193-197. https://doi.org/10.1016/j.bse.2011.02.008

\section{General rights}

Copyright and moral rights for the publications made accessible in the public portal are retained by the authors and/or other copyright owners and it is a condition of accessing publications that users recognise and abide by the legal requirements associated with these rights.

- Users may download and print one copy of any publication from the public portal for the purpose of private study or research.

- You may not further distribute the material or use it for any profit-making activity or commercial gain

- You may freely distribute the URL identifying the publication in the public portal 


\section{A new phenylethanoid triglycoside in Veronica beccabunga $\mathrm{L}$}

Søren Rosendal Jensen, ${ }^{\mathrm{a}, *}$ Sebastian Ed Wieland Opitz, ${ }^{\mathrm{b}}$ Charlotte Held Gotfredsen ${ }^{\mathrm{a}}$

${ }^{a}$ Department of Chemistry, The Technical University of Denmark, DK-2800, Lyngby, Denmark

${ }^{\mathrm{b}}$ Department of Chemical Ecology, Bielefeld University, D-33615 Bielefeld, Germany

* Corresponding author. Tel.: +45-45252103; fax: +45-45933968.

E-mail address: srj@kemi.dtu.dk (S.R. Jensen). 


\begin{abstract}
Besides the expected iridoid glucosides aucubin and catalpol as well as three known esters of the latter, Veronica beccabunga (brooklime) was shown to contain five carboxylated iridoid glucosides, namely gardoside, mussaenosidic acid, 8-epiloganic acid, arborescosidic acid and alpinoside. In addition to these compounds, the plant contained salidroside and a previously unknown caffeoyl phenylethanoid glycoside (CPG) which we have named chionoside J. The structure was elucidated mainly by 1D and 2D NMR spectroscopy to be 2"-( $\beta$-glucopyranosyl)-plantamajoside. The distribution of plantamajoside and its derivatives as well as that of carbocyclic iridoids with an 8,9-double bond is briefly discussed, and it is noted that such compounds are mainly confined to the tribe Veroniceae of the Plantaginaceae.
\end{abstract}

Keywords: Veronica beccabunga; Plantaginaceae; Mannitol; Iridoid glucoside; Phenylethanoid glycoside; Chionoside J 


\section{Introduction}

Plants of the genus Veronica (Speedwell, Plantaginaceae) have traditionally been considered members of the family Scrophulariaceae; however, the genus has recently been transferred to the Plantaginaceae on the basis of DNA sequence investigations (Olmstead et al., 2001; Albach et al., 2005). The chemistry of Veronica has been investigated intensively and the genus usually contains the iridoid glucosides aucubin (6) and catalpol (7) together with a variety of aromatic esters of the latter (GrayerBarkmeijer, 1978; Taskova et al., 2004; Jensen et al., 2005). In connection with an ongoing work on sequestration of plant secondary metabolites in phytophagous insects (Opitz et al., 2010), we undertook a chemical investigation of $V$. beccabunga L. (brooklime). This species has previously been investigated using chromatographic methods (Grayer-Barkmeijer, 1978; Taskova et al., 2004; Crisan et al., 2010), but apparently no isolation of the glycosidic compounds has been reported so far.

\section{Materials and methods}

\subsection{General}

Chromatography was performed on a Merck Lobar RP-18 column (size B) eluting with $\mathrm{H}_{2} \mathrm{O}-\mathrm{MeOH}$ mixtures (1:0 to 1:1); compounds are listed in order of elution; the amount of mannitol (1) was estimated from the ${ }^{13} \mathrm{C}$ NMR spectrum of the crude sugar fraction. NMR spectra were recorded on a Varian Unity Inova-500 $\mathrm{MHz}\left({ }^{1} \mathrm{H}\right)$ or Mercury-300 MHz $\left({ }^{13} \mathrm{C}\right.$ ) instrument in $\mathrm{MeOH}-d_{4}$ using the solvent peak $(\delta 3.30$ or 49.0) as the internal standard. 2D DQF-COSY, gHSQC, HMBC and NOESY spectra were acquired using standard pulse sequences. LC-HR ESIMS was performed on an Agilent HP 1100 Liquid Chromatograph equipped with a BDS-C18 reversed phase 
column running a water-acetonitrile (50 ppm TFA in water) gradient. The LC was coupled to a LCT of a TOF MS (Micromass, Manchester, UK) operated in the positive electrospray ion mode using 5-leucineenkephalin as lock mass.

The known compounds isolated were identified by their NMR data: mannitol (1), (Bock and Pedersen, 1983); iridoids 2-7 and salidroside (8) with authentic samples (Rønsted et al., 2000); veronicoside (7a) (Sticher and Afifi-Yazar, 1979a); verproside (7b) (Afifi-Yazar and Sticher, 1980); amphicoside (7c) (Kapoor et al., 1971); verminoside (7d) (Sticher and Afifi-Yazar, 1979b).

\subsection{Plant material}

V. beccabunga was grown from seeds (IPEN no. DE-0-B-2250905) from the Botanical Garden and Botanical Museum of Berlin-Dahlem, Germany, where a voucher specimen (B 10 0342111) is deposited at the Herbarium B. The seeds were sown once and subsequently propagated by cuttings which were harvested in March 2009.

\subsection{Work-up}

Dry foliage (21 g) was homogenized with boiling EtOH (150 ml) and filtered. The concentrated extracts were partitioned in $\mathrm{Et}_{2} \mathrm{O}-\mathrm{H}_{2} \mathrm{O}$, after which the aq. phase was dried to give $2.1 \mathrm{~g}$ of crude extract; chromatography of an aliquot (1.2 g, after dissolving in 10\% acetic acid) gave a sugar fraction (650 mg, with ca. 50\% mannitol (1)); catalpol (7; $10 \mathrm{mg})$; aucubin (6; $30 \mathrm{mg})$; a 3:1 mixt. of gardoside and mussaenosidic acid (2 and 3; $10 \mathrm{mg})$; a 1:1 mixt. of epiloganic acid and salidroside (3 and 8; $50 \mathrm{mg}$ ); arborescosidic acid (5; $50 \mathrm{mg})$; verproside (7b; $70 \mathrm{mg}$ ); a fract. A containing 7b, alpinoside (5a) and an unknown (9) in the proportion 2:1:3 (50 mg); a 
1:1 mixt. of amphicoside and verminoside (7c and 7d; $240 \mathrm{mg}$ ); verminoside (7d; 50 mg); and veronicoside (7a; $40 \mathrm{mg}$ ).

\subsection{Rechromatography of fract. A}

Chromatography of Fraction A on a Merck HiBar column (250-25) packed with LiChrosorb RP-18 gave a fraction (11 mg) containing the pure $\mathbf{9}$.

\subsection{Chionoside J (9)}

Isolated as a glass: $[\alpha]_{\mathrm{D}}{ }^{20}=-6^{\circ}(\mathrm{MeOH} ; \mathrm{c} 1.2) ;{ }^{1} \mathrm{H}$ and ${ }^{13} \mathrm{C}$ NMR in Table 1 ; LC-HR ESIMS m/z: $825.2403[\mathrm{M}+\mathrm{Na}]^{+} ;\left(\mathrm{C}_{35} \mathrm{H}_{46} \mathrm{NaO}_{21}\right.$ requires 825.2429).

\section{Results and Discussion}

\subsection{Isolated compounds}

The dry plant material was briefly boiled with ethanol and after extraction, the watersoluble part of the extract was subjected to reverse phase column chromatography and the isolated compounds were characterized by their NMR spectra (see section 2.1). Mannitol (1) was the main carbohydrate present. The following iridoid acids were isolated: mussaenosidic acid (2), 8-epiloganic acid (3), gardoside (4) and arborescosidic acid (5) as well as its acetyl ester alpinoside (5a). Furthermore we found the expected aucubin (6), as well as a little catalpol (7) in addition to the catalpol esters (7a-7d). Aside from the iridoid glucosides we also isolated salidroside (8) and a new caffeoyl phenylethanoid glycoside (CPG) (9).

Compound 9 was isolated as a colourless glass, $[\alpha]_{D}{ }^{20}=-6^{\circ}$. The molecular formula was $\mathrm{C}_{35} \mathrm{H}_{46} \mathrm{O}_{21}$ as deduced from the quasimolecular ion obtained by LC-HR ESIMS (observed m/z 825.2403 [M + Na]+). The NMR spectroscopic data (Table 1) could be 
assigned by interpretation of the 1D and 2D (DQF-COSY, gHSQC and gHMBC) spectra. Thus, the ${ }^{13} \mathrm{C}$ NMR spectrum of 9 exhibited the expected 35 signals; by comparison with model compounds, eight of these could be assigned to a 3,4dihydroxy-phenylethyl group and another set of nine resonances could be allocated to a caffeoyl ester moiety. The remaining 18 signals were surmised to belong to three hexoaldoside units since three of them were found in the 103 to $106 \mathrm{ppm}$ region of the spectrum, the shift values signifying anomeric carbon atoms, while the remaining 15 signals were found between 62 and $86 \mathrm{ppm}$. One anomeric signal at $\delta_{\mathrm{C}} 103.3$ could be assigned as C-1' since it exhibited a cross-peak with $\mathrm{H}-8\left(\delta_{\mathrm{H}} 3.72\right)$ of the $3,4-$ dihydroxy-phenylethyl group in the HMBC spectrum. This allowed us to assign H-1' and using the COSY and the HSQC spectra, we could likewise assign the remaining proton and carbon signals arising from a central $\beta$-glucopyranosyl moiety (see Table 1), taking in account also the visible ${ }^{1} \mathrm{H}$ coupling pattern. The position of the caffeoyl ester group at the C-4' carbon atom was seen both from the low field absorption of $\mathrm{H}$ 4' $\left(\delta_{\mathrm{H}} 4.93\right)$, and from the presence of a HMBC correlation between $\mathrm{H}-4$ ' and the carbon atom of the CO'"'-group of the caffeoyl moiety. The low field resonance shift of the signals from $\mathrm{C}-3^{\prime}\left(\delta_{\mathrm{C}} 85.6\right)$ and $\mathrm{H}-3^{\prime}\left(\delta_{\mathrm{H}} 3.88\right)$, showed that this was the linkage position to a second glycosyl unit. Another HMBC correlation from H-3' to C-1" $\left(\delta_{C}\right.$ 104.1), made it possible to identify the anomeric carbon of this second (inner) glycosyl unit, and as above, the 2D NMR spectral data now allowed to assign the remaining resonances from this hexopyranosyl unit. Also this unit had a carbon signal with a low field resonance, namely C-2" $\left(\delta_{C} 84.5\right)$, and a cross-peak in the HMBC spectrum from the corresponding proton, $\mathrm{H}-2$ " $\left(\delta_{\mathrm{H}} 3.36\right)$ to the last unassigned anomeric carbon atom C-1"' $\left(\delta_{\mathrm{C}} 105.7\right)$ confirmed that the third (outer) hexopyranosyl moiety was indeed sited at this position. Comparison of $\delta_{\mathrm{C}^{\prime \prime}}$ together with the 
remaining five unassigned carbon signals with model compounds (10 and $\mathbf{1 1}$, Table 1) confirmed that these belonged to another $\beta$-glucopyranosyl moiety. Furthermore, comparison of the carbon NMR data assigned to the second (inner) hexopyranosyl unit with the model compound $\mathbf{1 0}$, similarly confirmed that this also had to be a $\beta$ glucopyranosyl moiety. In conclusion, compound 9 is $\beta$-glucopyranosyl-( $1 \rightarrow 2)-\beta$-Dglucopyranosyl-( $1 \rightarrow 3)$-calceolarioside A or 2"-( $\beta$-glucopyranosyl)-plantamajoside, and we have named it chionoside $\mathrm{J}$, since the isomeric compound $\mathbf{1 1}$ from Veronica thomsonii (Buchanan) Cheeseman has previously been named isochionoside J (Taskova et al., 2010).

The above structural elucidation has mainly been based on the similarity of the ${ }^{13} \mathrm{C}$ NMR data. In contrast, when considering the ${ }^{1} \mathrm{H}$ NMR data, we see that the shift values for the H-2" to H-6" are much more dissimilar in chionoside J (9) and its isoform (11). This must be ascribed to the difference in shielding effect of the aromatic ring of the ester moiety, changing from the 4'- to the 6'-position. Such an effect is apparently not important for the ${ }^{13} \mathrm{C}$ chemical shifts.

\subsection{Chemotaxonomy}

Caffeoyl phenylethanoid glycosides (CPGs) are very common in the plant order Lamiales. However, CPGs with a 3'-O-glucosyl substituent (i. e. derivatives of plantamajoside, 12) have almost exclusively been reported from Plantaginaceae and mainly from Plantago (Rønsted et al., 2000) and from Veronica and its allies in Veroniceae (Taskova et al., 2006). The only exceptions are 12 and purpureaside B from cell-cultures of Rehmannia glutinosa Libosch, Rehmanniaceae ( Shoyama et al., 1986); artselaeroside B from Pedicularis artselaeri Maxim., Orobanchaceae (Su et al., 1998); 12 has also been reported from three species of Gesneriaceae, namely 
Aeschynanthus speciosus Hook. (Jensen, 1996), Chirita longgangensis W.T. Wang (Wang et al., 2005) and Chirita eburnea Hance (Chen et al., 2010), and finally, it has been found in Mimulus cardinalis Douglas ex Benth., Phrymaceae (Jensen, unpubl). Another kind of compound of special taxonomic interest are the iridoid glucosides with an 8,9-double bond, such as $\mathbf{5}$ and $\mathbf{5 a}$. We have previously noted (Albach et al., 2004) that compounds with this structural feature are solely reported from genera within the tribe Veroniceae of the Plantaginaceae, namely Globularia, Paederota, Plantago, Veronica and Wulfenia. Since this, such compounds have furthermore been found in Erinus (Taskova et al., 2005), and more recently also in Lagotis (Jensen et al., 2009).

\section{Acknowledgement}

We thank Dr. Kristian Fog Nielsen, BioCentrum, DTU, for recording the mass spectrum.

\section{References}

Afifi-Yazar, F. U., Sticher, O., 1980. Verproside, a new iridoid glucoside from Veronica officinalis L. (Scrophulariaceae). Helv. Chim. Acta 63, 1905-1907.

Albach, D. C., Meudt, H. M., Oxelman, B., 2005. Piecing together the "new" Plantaginaceae. Am. J. Bot. 92, 297-315.

Bock, K., Pedersen, C., 1983. Carbon-13 nuclear magnetic resonance spectroscopy of monosaccharides. Adv. Carbohydrate Chem. Biochem. 41, 27-66. 
Chen, W., Li, D., Chen, Y., Huang, Y., Wen, Y., 2010. Preparation of five phenylethanoid glycoside components by semi-preparative HPLC. Guangxi Zhiwu 30, 269-273.

Crisan, G., Vlase, L., Balica, G., Muntean, D., Stefanescu, C., Paltinean, R., Tamas, M., Leucuta, S., 2010. LC/MS analysis of aucubin and catalpol of some Veronica species. Farmacia 58, 237-242.

Grayer-Barkmeijer, R. J., 1979. Chemosystematic investigations in Veronica L. (Scrophulariaceae) and related genera. PhD Thesis, Univ. of Leiden, The Netherlands.

Jensen, S. R., 1996. Caffeoyl phenylethanoid glycosides in Sanango racemosum and in the Gesneriaceae. Phytochemistry 43, 777-783.

Jensen, S. R., Albach, D. C., Ohno, T., Grayer, R. J., 2005. Veronica: Iridoids and cornoside as chemosystematic markers. Biochem. Syst. Ecol. 33, 1031-1047.

Jensen, S. R., Gotfredsen, C. H., Zidorn, C., 2009. Iridoids and phenylethanoids in Lagotis integrifolia and Wulfeniopsis amherstiana (Plantaginaceae). Biochem. Syst. Ecol. 37, 421-425.

Kapoor, S. K., Kohli, J. M., Zaman, A., 1971. Amphicoside. I. New bitter glycoside from Amphicome emodi. Tetrahedron Lett. 12, 2839-2840.

Li, J. X., Li, P., Tezuka, Y., Namba, T., Kadota, S., 1998. Three phenylethanoid 
glycosides and an iridoid glycoside from Picrorhiza scrophulariiflora. Phytochemistry 48, 537-542.

Maggi, A., Taskova, R. M., Gotfredsen, C. H., Bianco, A. \& Jensen, S. R., 2009. Chemical markers in Veronica sect. Hebe. III. Biochem. Syst. \& Ecol. 37, 731-736.

Olmstead, R. G., DePamphilis, C. W., Wolfe, A. D., Young, N. D., Elisons, W. J., Reeves, P. A., 2001. Disintegration of the Scrophulariaceae. Am. J. Bot. 88, $348-361$.

Opitz, S. E. W., Jensen, S. R., Müller, C., 2010. Sequestration of glucosinolates and iridoid glucosides in sawfly species of the genus Athalia and their role in defense against ants. J. Chem. Ecol. 36, 148-157.

Rønsted, N., Göbel, E., Franzyk, H., Jensen, S. R., Olsen, C. E., 2000. Chemotaxonomy of Plantago. Iridoid glucosides and caffeoyl phenylethanoid glycosides. Phytochemistry, 55, 337-348.

Shoyama, Yukihiro; Matsumoto, Masami; Nishioka, Itsuo., 1986. Four caffeoyl glycosides from callus tissue of Rehmannia glutinosa. Phytochemistry (1986), 25(7), 1633-6.

Sticher, O., Afifi-Yazar, F. U., 1979a. Veronicoside, a new iridoid glucoside from Veronica officinalis L. (Scrophulariaceae). Helv. Chim. Acta 62, 530-534. 
Sticher, O., Afifi-Yazar, F. U., 1979b. Minecoside and verminoside, two new iridoid glucosides from Veronica officinalis L. (Scrophulariaceae). Helv. Chim. Acta 62, 535-539.

Su, B. N., Ma, L. P., Jia, Z. J., 1998. Iridoid and phenylethanoid glycosides from Pedicularis artslaeri. Planta Med. 64, 720-723.

Taskova, R. M., Albach, D. C., Grayer, R. J., 2004. Phylogeny of Veronica - a combination of molecular and chemical evidence. Plant Biol. 6, 673-682.

Taskova, R. M., Gotfredsen, C. H., Jensen, S. R., 2005. Chemotaxonomic markers in Digitalideae (Plantaginaceae). Phytochemistry 66, 1440-1447.

Taskova, R. M., Gotfredsen, C. H,. Jensen, S. R., 2006. Chemotaxonomy of Veroniceae and its allies in the Plantaginaceae. Phytochemistry 67, 286-301.

Taskova, R.M., Kukubun, T., Ryan, K.G., Garnock-Jones, P.J., Jensen, S.R., 2010. Iridoid and phenylethanoid glycosides in the New Zealand snow hebes (Veronica, Plantaginaceae). Chem. Pharm. Bull. 58, 703-711

Wang, M., Yang, L., Tu, Y., 2005. Phenylethanoid glycosides from stem of Chirita longgangensis var. hongyao. Zhongguo Zhongyao Zazhi 30, 1921-1923. 
Table 1. ${ }^{1} \mathrm{H}(500 \mathrm{MHz})$ and ${ }^{13} \mathrm{C}$ NMR (125 MHz) spectra of 9 and model compounds in $\mathrm{CD}_{3} \mathrm{OD}$.

\begin{tabular}{|c|c|c|c|c|c|c|}
\hline Atom & \multicolumn{2}{|l|}{$\begin{array}{c}\text { Chionioside J } \\
\text { (9) }\end{array}$} & $\begin{array}{c}\text { Scroside C } \\
\text { (10) }^{\text {a }}\end{array}$ & \multicolumn{2}{|c|}{$\begin{array}{c}\text { Isochionoside J } \\
(\mathbf{1 1})^{\mathrm{b}}\end{array}$} & $\begin{array}{c}\text { Plantamajoside } \\
\mathbf{( 1 2}^{\mathrm{c}}\end{array}$ \\
\hline & ${ }^{1} \mathrm{H}-\delta$ (mult. Hz) ${ }^{\mathrm{d}}$ & ${ }^{13} \mathrm{C}$ & ${ }^{13} \mathrm{C}$ & ${ }^{1} \mathrm{H}-\delta$ (mult. Hz) ${ }^{\mathrm{d}}$ & ${ }^{13} \mathrm{C}$ & ${ }^{13} \mathrm{C}$ \\
\hline \multicolumn{7}{|l|}{ Agluc } \\
\hline 1 & & 131.5 & 132.3 & & 131.4 & 131.5 \\
\hline 2 & $6.71(\mathrm{~d}, 1.9)$ & 117.2 & 117.6 & $6.68(\mathrm{~d}, 2.0)$ & 117.2 & 117.2 \\
\hline 3 & & 146.1 & 148.8 & & 146.1 & 145.8 \\
\hline 4 & & 144.6 & 147.2 & & 144.6 & 144.2 \\
\hline 5 & 6.67 (d 8.0) & 116.3 & 112.7 & $6.62(\mathrm{~d}, 8.0)$ & 116.3 & 116.5 \\
\hline 6 & $6.56(\mathrm{dd}, 1.9,8.0)$ & 121.3 & 120.1 & $6.53(\mathrm{dd}, 2.0,8.0)$ & 121.3 & 121.5 \\
\hline 7 & $2.782 \mathrm{H}(\mathrm{m})$ & 36.5 & 36.1 & $2.77(2 \mathrm{H}, \mathrm{m})$ & 36.7 & 36.3 \\
\hline 8 & 3.72/4.04 (m's) & 72.2 & 71.1 & $3.72,3.95(\mathrm{~m} / \mathrm{s})$ & 72.3 & 72.2 \\
\hline \multicolumn{7}{|l|}{ Central Glc } \\
\hline $1^{\prime}$ & $4.45(\mathrm{~d} 8.0)$ & 103.3 & 103.2 & $4.43(\mathrm{~d}, 7.0)$ & 103.5 & 103.7 \\
\hline $2^{\prime}$ & 3.54 (obsc) & 74.6 & 74.4 & 3.50 obsc. & 73.8 & 75.7 \\
\hline $3^{\prime}$ & 3.88 (t 9.1) & 85.6 & 86.2 & 3.50 obsc. & 89.9 & 83.8 \\
\hline $4^{\prime}$ & $4.93(\mathrm{t} 9.3)$ & 70.8 & 70.3 & 3.50 obsc. & 70.1 & 70.7 \\
\hline $5^{\prime}$ & 3.53 (obsc) & 75.9 & 76.4 & 3.59 obsc. & 75.0 & 75.5 \\
\hline \multirow[t]{2}{*}{$6^{\prime}$} & 3.53 (obsc) & 62.3 & 62.6 & $4.33(\mathrm{dd}, 5.9,11.8)$ & 64.5 & 62.1 \\
\hline & 3.63 (br. d 10) & & & $4.50(\mathrm{dd}, 1.5,11.8)$ & & \\
\hline \multicolumn{7}{|c|}{ 3'-Glc (inner) } \\
\hline $1^{\prime \prime}$ & 4.62 (d 7.2) & 104.1 & 104.6 & $4.62(\mathrm{~d}, 7.8)$ & 104.0 & 104.8 \\
\hline $2^{\prime \prime}$ & 3.36 (obsc) & 84.5 & 85.3 & 3.50 obsc. & 85.1 & 74.8 \\
\hline $3^{\prime \prime}$ & 3.55 (obsc) & 76.6 & 77.6 & $3.39(\mathrm{t}, 9.3)$ & 77.6 & 77.3 \\
\hline $4^{\prime \prime}$ & 3.27 (obsc) & 70.8 & 71.2 & 3.35 obsc. & 71.0 & 71.0 \\
\hline $5^{\prime \prime}$ & $3.14(\mathrm{~m})$ & 77.5 & 78.1 & 3.35 obsc. & 78.0 & 77.6 \\
\hline \multirow[t]{2}{*}{$6^{\prime \prime}$} & 3.47 (dd, 4.9, 11.9) & 62.3 & 62.2 & $3.63(\mathrm{dd}, 5.7,12.0)$ & 62.4 & 62.1 \\
\hline & 3.68 (obsc) & & & 3.87 (br. d, 11.5) & & \\
\hline \multicolumn{7}{|c|}{ 2"-Glc (outer) } \\
\hline $1^{\prime \prime \prime}$ & 4.64 (d 7.2) & 105.7 & 106.4 & $4.61(\mathrm{~d}, 7.7)$ & 106.4 & \\
\hline $2^{\prime \prime \prime}$ & 3.25 (obsc) & 76.1 & 76.7 & 3.27 (dd 7.7, 9.2) & 76.2 & \\
\hline $3^{\prime \prime \prime}$ & 3.36 (obsc) & 77.6 & 77.6 & 3.38 obsc. & 77.6 & \\
\hline $4^{\prime \prime \prime}$ & 3.37 (obsc) & 70.9 & 71.2 & 3.35 obsc. & 71.2 & \\
\hline $5^{\prime \prime \prime}$ & 3.36 (obsc) & 78.6 & 78.1 & 3.36 obsc. & 78.8 & \\
\hline \multirow[t]{2}{*}{$6^{\prime \prime \prime}$} & 3.75 (obsc) & 62.2 & 62.2 & $3.73(\mathrm{dd}, 4.6,12.0)$ & 62.3 & \\
\hline & 3.92 (br. d 11.9) & & & 3.91(dd, 1.8, 12.0) & & \\
\hline 4'-Acyl & 4'-Caffeoyl & & 4'-Feruloyl & 4'-Caffeoyl & & 4'-Caffeoyl \\
\hline $1^{\prime \prime \prime \prime}$ & & 127.6 & 126.8 & & 127.6 & 127.6 \\
\hline $2^{\prime \prime \prime \prime}$ & $7.06(\mathrm{~d}, 1.7)$ & 115.3 & 111.5 & $7.03(\mathrm{~d}, 2.0)$ & 114.8 & 115.0 \\
\hline $3^{\prime \prime \prime \prime}$ & & 146.8 & 149.1 & & 146.8 & 146.5 \\
\hline $4^{\prime \prime \prime \prime}$ & & 149.7 & 151.1 & & 149.6 & 149.4 \\
\hline $5^{\prime \prime \prime \prime}$ & $6.78(\mathrm{~d} 8.2)$ & 116.6 & 116.7 & $6.76(\mathrm{~d}, 8.2)$ & 116.5 & 116.7 \\
\hline $6^{\prime \prime \prime \prime}$ & $6.98(\mathrm{dd}, 1.7,8.2)$ & 123.2 & 124.0 & $6.89(\mathrm{dd}, 2.0,8.2)$ & 123.2 & 123.3 \\
\hline$\alpha^{\prime \prime \prime \prime}$ & $6.33(\mathrm{~d} 15.9)$ & 115.1 & 115.9 & $6.28(\mathrm{~d}, 15.9)$ & 115.0 & 147.6 \\
\hline$\beta^{\prime \prime \prime \prime}$ & 7.58 (d 15.9) & 147.6 & 146.0 & 7.55 (d, 15.9) & 147.2 & 115.3 \\
\hline \multirow[t]{2}{*}{$\mathrm{CO}^{\prime \prime \prime \prime}$} & & 168.5 & 167.4 & & 169.1 & 168.7 \\
\hline & & & 55.9 & & & \\
\hline
\end{tabular}


\begin{tabular}{|c}
$\mathrm{OH}$ \\
$-\mathrm{OH}$ \\
$\mathrm{OH}$ \\
$\mathrm{OH}$
\end{tabular}

1; Mannitol<smiles>CC(=O)O[C@H]1OC=C(C(=O)O)C2CC[C@](C)(O)[C@H]21</smiles>

2; Mussaenosidic acid<smiles>CC(=O)O[C@H]1OC=C(C(=O)O)C2C[C@H](O)[C@@H](C)C21</smiles>

3; 8-Epiloganic acid<smiles>C=C1C2C(C[C@H]1O)C(C(=O)O)=CO[C@@H]2OC</smiles>

4; Gardoside<smiles>[R6]CC1=C2C(C(=O)O)=CO[C@H](O)O[C@@H]2CC1</smiles>

5; $\mathrm{R}=\mathrm{H}$; Arborescosidic acid 5a; R=Acetyl; Alpinoside<smiles>OCC1=C[C@@H](O)C2C=CO[C@@H](Cl)[C@H]12</smiles>

6; Aucubin

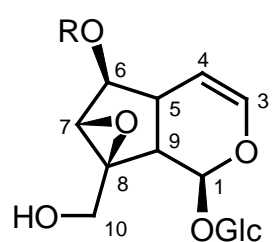

7; $\mathrm{R}=\mathrm{H}$; Catalpol

7a; $\mathrm{R}=$ Benzoyl; Veronicoside

7b; $\mathrm{R}=3,4$-di-OH-Benzoyl; Verproside

7c; R=Vanilloyl; Amphicoside

7d; R=Caffeoyl; Verminoside

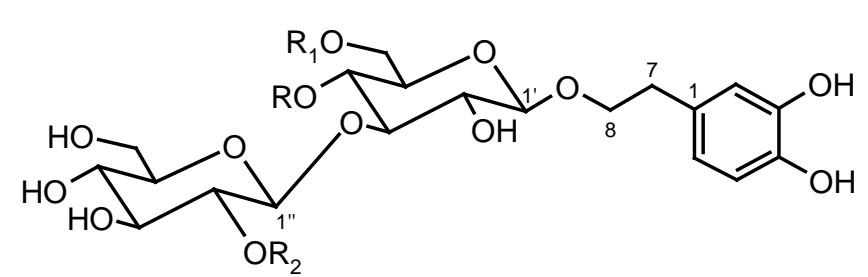

9; R=Caffeoyl; $\mathrm{R}_{1}=\mathrm{H} ; \mathrm{R}_{2}=\mathrm{Glc}$; Chionoside J

10; $\mathrm{R}=\mathrm{H} ; \mathrm{R}_{1}=$ Feruloyl; $\mathrm{R}_{2}=\mathrm{Glc}$; Scroside $\mathrm{C}$

11; $\mathrm{R}=\mathrm{H} ; \mathrm{R}_{1}=$ Caffeoyl; $\mathrm{R}_{2}=\mathrm{Glc}$; Isochionoside $\mathrm{J}$

12; R=H; $\mathrm{R}_{1}=$ Caffeoyl; $\mathrm{R}_{2}=\mathrm{H} ;$ Plantamajoside<smiles>Oc1ccc(CCOC(Cl)Cl)cc1</smiles>

8; Salidroside 